\title{
Rutting Behaviour of Fallow Deer
}

\author{
Francisco BRAZA, Juan E. GARCIA \& Fernando ALVAREZ
}

Braza F., García J. E. \& Alvarez F., 1986: Rutting behaviour of fallow deer. Acta theriol., 31, 34: 467-478 [With 2 Tables \& 5 Figs.]

During three years from 1982 to 1984 the rutting behaviour of fallow deer was studied at the Doñana Reserve (Southwestern Spain). Timing of rutting season is constant across years, starting suddenly at the beginning of October, remaining at a high level for the first two weeks, extending for one more week and then decreasing gradually through the autumn. Average harem size does not vary much across seasons (from 9.1 to 10.6 individuals) but during the 1982 period, when for the first time the spring rains reached normal level after a period of severe draught, the number of harems was at its lowest level, whereas female membership in those harems was the highest. The smaller number of bucks holding harems in 1982 showed higher values of individual reproductive success than during subsequent years. The peak of the rutting period coincides with maxima of groaning and of interactions both towards males and females, whereas grazing is at its lowest level. Marking activity starts with high values at the beginning of the rutting season and decreases gradually. The more successful nales show an attachment to particular rutting areas.

[Estación Biológica Doñana, Departamento de Etología, Apartado 1056, Sevilla, Spain].

\section{INTRODUCTION}

Aspects of deer sexual cycle and rutting behaviour have received increasing attention in the last decade, among them the members of the genus Cervus being the most studied, whereas the closely related fallow deer (Dama) has received little attention.

The few studies of fallow deer's rutting behaviour published have concentrated on aspects of grouping pattern, behaviour of the master bucks and use of space (Heidemann, 1973; Espmark \& Brunner, 1974; Alvarez et al., 1975; Jodra, 1981; Schaal, 1985).

The characteristic rutting groups are usually made up of several females with their young and only one adult male, which dedicates most of his time to mark rutting stands, to retrieve females to his harem and to expel intruders from it, spending less time feeding than other age and sex classes.

In order to extend the general view of reproductive behaviour in the 
Cervidue we have concentrated on little known aspects of fallow deer rutting behaviour, such as grouping patterns, factors affecting reproductive success, time budget, social interactions and use of space.

\section{METHODS}

The study area is located in the National Park of Donana (Southwestern Spain), at the mouth of the Guadalquivir River, where the principal environmental units are dunes, low shrub, marshlands and its periphery. About 83 per cent of the fallow deer of the National Park live in the marsh periphery (Braza, 1975), this ecotone consisting mainly of different kinds of meadows and areas of rushes. A detailed description of the habitats can be seen in Braza and Alvarez (in press).

Between the 15th of September and the 15th of November of 1982, 1983 and 1984 we concentrated on the fallow deer living in the narrow zone of $6 \mathrm{~km}$ by approximately $1.5 \mathrm{~km}$ ecotone of the inner Biological Reserve, containing about 25 per cent of the total fallow deer population (Ojeda et al., 1983).

The study period started just after a period of draught, as shown by the mean annual rainfall (1980: $386 \mathrm{~mm}, 1981: 317 \mathrm{~mm}, 1982: 561 \mathrm{~mm}$, 1983: $556 \mathrm{~mm}$, 1984: $461 \mathrm{~mm}$ ). Besides, although during 1983 and 1984 mean rainfall values were normal, winter and spring rains were scarce, having an effect on pasture production, as shown, for example, in shoot density per square meter of Scirpus maritimus (1981: no production, 1982: 203, 1983: no production, 1984: 117, 1985: 251; Amat, pers. commun.).

The autumn fallow deer population of the study area varied from a mean of 165 individuals in 1982 to 265 in 1983 and to 279 in 1984, the low values of 1982 resulting of the high mortality due to draught and affecting mainly the fawns and other young animals.

In order to ascertain population size as well as grouping patterns, periodic counts were made in the whole area of study once a week during 1982 and every 4 days in 1983 and 1984. To that end we followed a fixed path in the early morning from which most of fallow deer present could be easily counted: driving a vehicle (Land-Rover) at 15 to $20 \mathrm{~km}$ per hour two observers (appart from the driver) registered location, animal numbers and group size and composition. Individuals were considered to belong to the same group if they were no farther than $50 \mathrm{~m}$ apart from each other.

Additionally, in the observational part of the study a restricted zone $3 \mathrm{~km}$ long of the study area was more frequently searched from the vehicle and from a tower $30 \mathrm{~m}$ high.

Fallow deer movements within the Biological Reserve and from other 
areas of the National Park are not obstructed, lack of restriction having an effect over the number of adult males and females in the study area (Braza et al., 1984), the former going up dramatically at the beginning of October $(1982, t=3.9, d f=9, p<0.01 ; 1983, t=6.1, d f=16$, $p<.001 ; 1984, t=5.5, d f=15, p<.001$ ), followed by a decrease at the start of November, the amount of females remaining unchanged from the summer to the autumn rutting season, but decreasing at the end of rut in November $(1982, t=6.3, d f=9, p<.001 ; 1983, t=3.6, d f=16$, $p<.01 ; 1984, t=6.7, d f=16, p<.001)$.

Behavioural data were collected following the focal-animal sampling method. Within the mixed group an individual was chosen at random with the only requirement that it would not be lying down and its behaviour was registered for at least $15 \mathrm{~min}$, the sequence of acts being divided into 1 -min intervals.

The following patterns of behaviour were registered:

a) Feeding: including drinking and grazing, either keeping still or while walking slowly without raising the head.

b) Locomotion: with head raised above shoulder level, the animal moves but not directly towards another individual.

c) Vigilance: while on all four, with ears oriented forward, the subject keeps its head raised, sometimes turning it to the right or to the left.

d) Marking: rubbing preorbital glands, cheeks or antlers against own body (sides, back or legs) or on landmarks in the environment (trees, trunks, etc.).

e) Interactions towards males: approaching, displacing receptor from previous place, chasing, parallel walking, initiating fight (lowering head towards receptor, in this way inviting contact), fighting (entangling antlers and pushing) and groaning towards males.

f) Interactions towards females: approaching, sniffing and licking female, male herding females (retrieving those females that get too far away from the harem and short chases within harem), moving tongue (with half open mouth the male sticks quickly and repetitively his tongue towards a female), resting chin (male resting chin or whole head against female's back or hindquarters), rubbing forehead and antlers on female's side, mounting and copulation attempts, groaning (sometimes produced by males while approaching, herding or chasing females).

g) Interactions towards fawns: Any behaviour directed towards fawns.

Sequences of behaviour were useful in the analysis of time budget of activities and to that end the proportion of 1 -min periods containing ach of the above described patterns of behaviour was calculated over che total time of observation.

Sex and age classes sociograms were obtained by analysing the se- 
quences of behaviour, using the interaction indices of Shank (1972).

The following age and sex classes were considered:

Fawns: males and females less than one year old; hinds: females older than one year; yearling males: between 1 and 2 years old; sub-adult males: $2-3$ years old; young adult males: $4-5$ years old, old males: 6 years old and above.

Every three days during the whole study period the frequency of groaning per minute was also registered from three fixed points in the meadows of the marsh periphery at the half hour with center in sunrise time.

\section{RESULTS}

\subsection{Grouping Pattern}

It can be seen in Fig. 1 how the pattern of variation in the occurrence of mixed groups (those containing at least an adult female and an adult or subadult male) is very similar for the three study periods, that is,

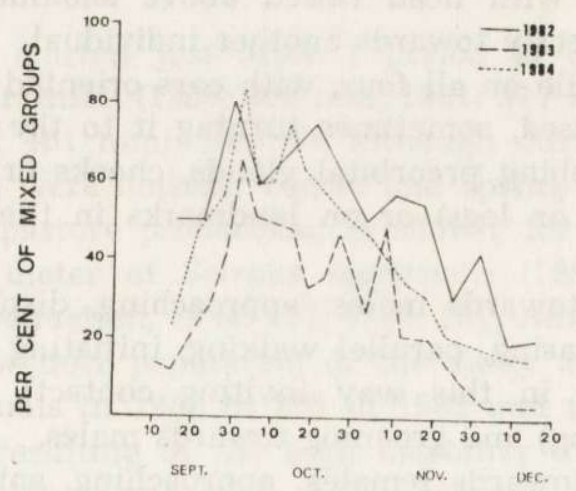

Fig. 1. Variation in the proportion of mixed groups in the three study periods.

from a rather low value at the middle of September, the occurrence of mixed groups goes up suddenly at the end of that month, descending gradually and reaching very low values by December.

Two kinds of mixed groups were considered: harems (those made up of one or more adult females accompanied by only a subadult male or an adult one, although the latter can be accompanied by younger males), and multi-male mixed groups (those containing at least an adult female and several adult or subadult males). Both kinds of groups may or may not include fawns and juveniles.

These two kinds of groups appear as quite different under all criteria considered (Table 1). Whereas multi-male groups occurrence did not 
vary much accross years, the number of harems in 1982 was less than half the values of successive years, the variation in group size and adult females' numbers remaining relatively constant in the three study periods.

Table 1

Features of the harem and multi-male mixed groups during the whole study period.

\begin{tabular}{|c|c|c|c|c|}
\hline Year & & 1982 & 1983 & 1984 \\
\hline \multicolumn{5}{|c|}{ Harems } \\
\hline \multirow[t]{2}{*}{ Numbers of groups } & $\overline{\mathrm{x}}$ & 4.4 & 9.2 & 9.2 \\
\hline & SD & 1.7 & 4.8 & 4.7 \\
\hline \multirow[t]{2}{*}{ Group size } & $\bar{x}$ & 10.6 & 9.1 & 10.3 \\
\hline & $\underset{\overline{\mathrm{x}}}{\mathrm{SD}}$ & 4.5 & $\begin{array}{l}4.4 \\
40\end{array}$ & $\begin{array}{l}4.2 \\
4.5\end{array}$ \\
\hline Number of adult females & SD & 2.6 & 2.4 & 1.8 \\
\hline \multicolumn{5}{|c|}{ Multi-male mixed groups } \\
\hline \multirow[t]{2}{*}{ Number of groups } & $\overline{\mathrm{x}}$ & 4.2 & 3.4 & 4.9 \\
\hline & SD & 1.8 & 2.5 & 2.6 \\
\hline \multirow[t]{2}{*}{ Group size } & $\bar{x}$ & 18.3 & 15.1 & 18.3 \\
\hline & SD & 5.9 & 4.1 & 6.1 \\
\hline Number of adult females & $\begin{array}{r}\bar{x} \\
S D\end{array}$ & $\begin{array}{l}8.3 \\
3.1\end{array}$ & $\begin{array}{l}6.2 \\
2.1\end{array}$ & $\begin{array}{l}6.7 \\
2.0\end{array}$ \\
\hline \multirow[t]{2}{*}{ Number of adult males } & $\overline{\mathrm{x}}$ & 3.1 & 2.6 & 2.8 \\
\hline & SD & 1.0 & 0.9 & 0.7 \\
\hline \multirow[t]{2}{*}{ Number of subadult males } & $\overline{\mathrm{x}}$ & 1.6 & 0.6 & 1.5 \\
\hline & SD & 1.2 & 0.4 & 1.7 \\
\hline
\end{tabular}
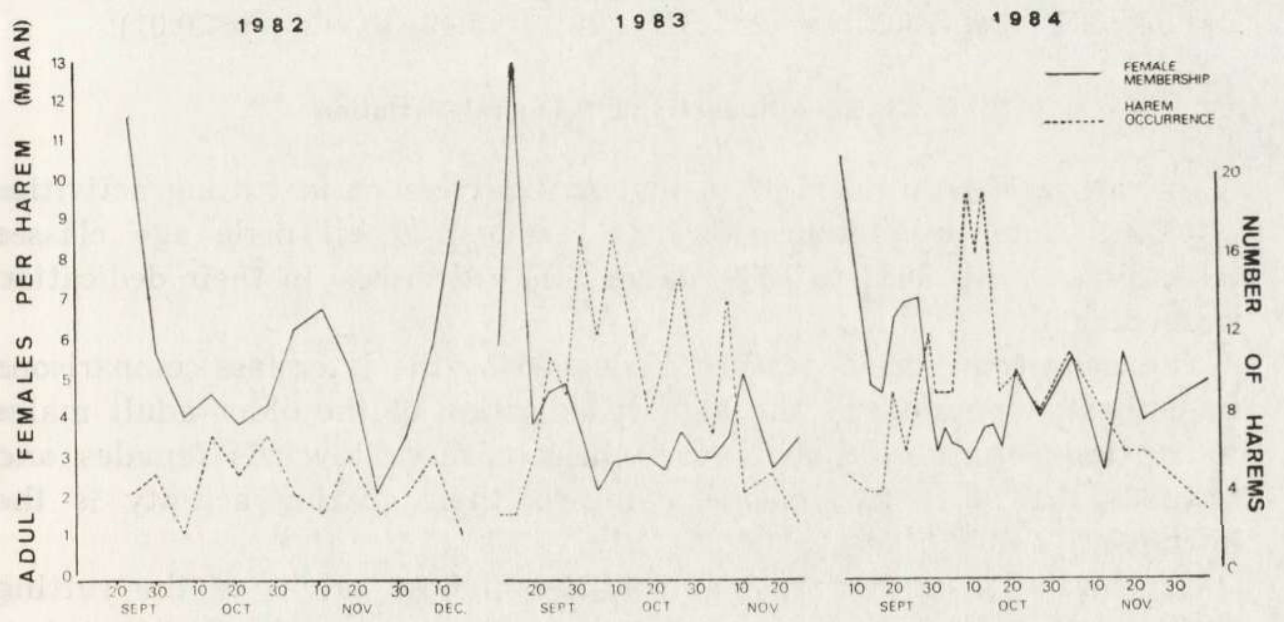

Fig. 2. Variation in time of harem occurrence and mean female membership. 
As to the variation in harem number and female membership (Fig. 2), the pattern is approximately the same for the three study periods, higher harem occurrence (also of lower female membership) taking place in the first three weeks of October, time at which the number of females per harem, in successive years from 1982, averaged 4.1, 2.7 and 3.2 , respectively. The pattern is specially evident in the last two study periods.

\subsection{Factors of Reproductive Success}

An estimate of reproductive success of each individual stag was obtained following the procedure of Gibson \& Guinness $(1980 \mathrm{a}, \mathrm{b})$ for red deer. In summary, the estimated number of calves sired by each stag was obtained by multiplying the number of hinds in his harem on each day of the rutting period, when information was available, by the proportion of hinds conceiving on each of those days, then adding the values over all days for each stag.

The proportion of hinds conceiving per day was calculated by multiplying fertility (proportion of hinds conceiving per year) by the relative proportion of conceptions on each day of the rutting period (derived from the smoothed distribution of births, the latter being normalized following the procedure of Gibson \& Guinness, 1980a). The considered value of the gestation period was of 229 days, according to Chapman \& Chapman (1975).

When comparing reproductive success of the adult males holding harems in the 1982 and 1983 rutting seasons, the values obtained for the former period came out as significantly higher than the latter (1982: $\bar{x}=.98, S D=.84 ; 1983: \bar{x}=.22, S D=.28 ; t=3.49, d f=38, p<0.01)$.

\subsection{Time Budget and Temporal Variation}

As can be seen in Table 2, a higher involvement in rutting activities (vigilance and interactions towards females) of all male age classes takes place from 1982 to 1983 , as well as a decrease in their dedication to feeding.

The most conspicuous feature evidenced by the interclass comparisons in both study periods is the higher dedication of the older adult males to rutting activities, that is, they behave more towards females and towards the other two classes, whereas their grazing activity is the lowest.

As can be seen in Fig. 3 and 4, the highest values of the rutting activities (marking, groaning and interactions) occur in the first two weeks of October, the patterns of variation for each of these activities 


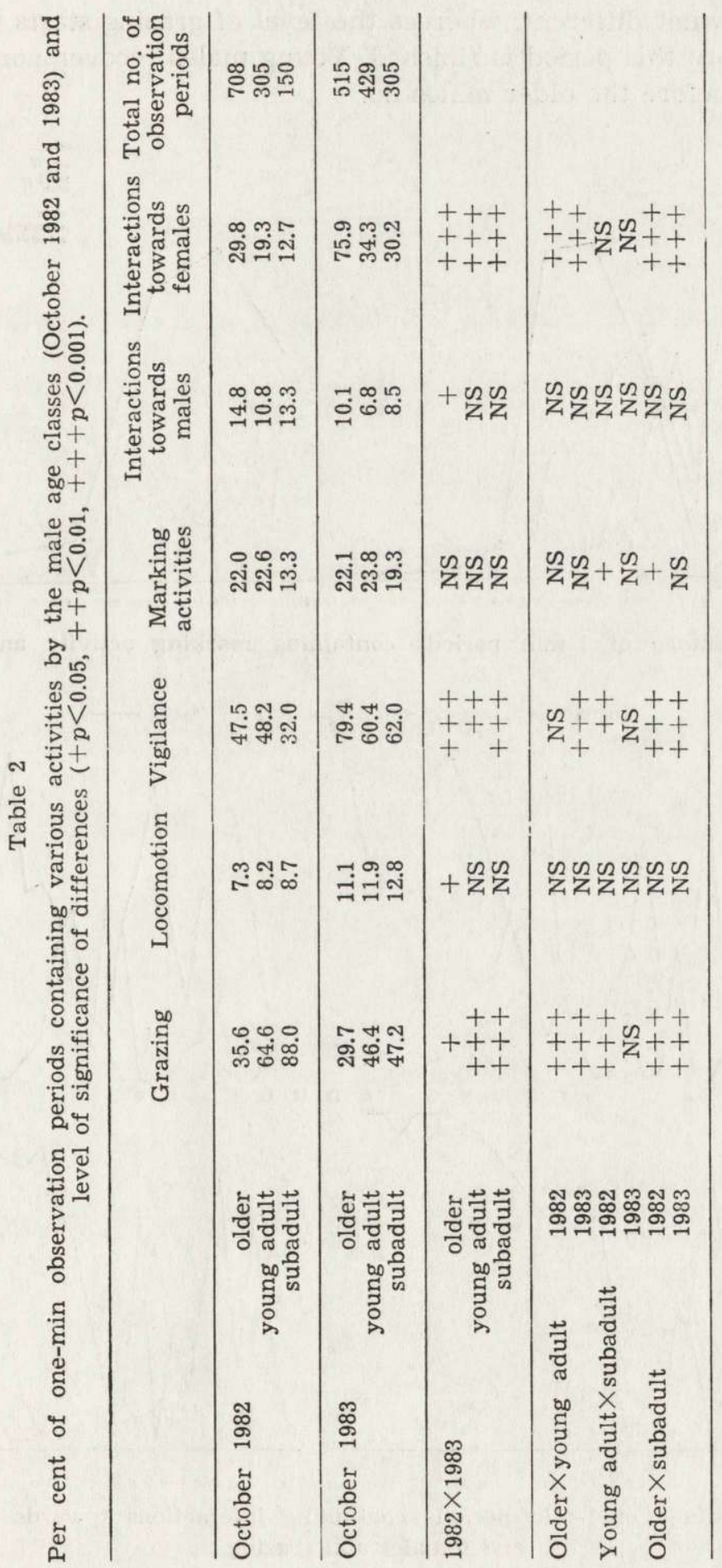


being somewhat different, whereas the level of grazing starts to increase a little before this period is finished. Young males recover normal levels of grazing before the older males do.

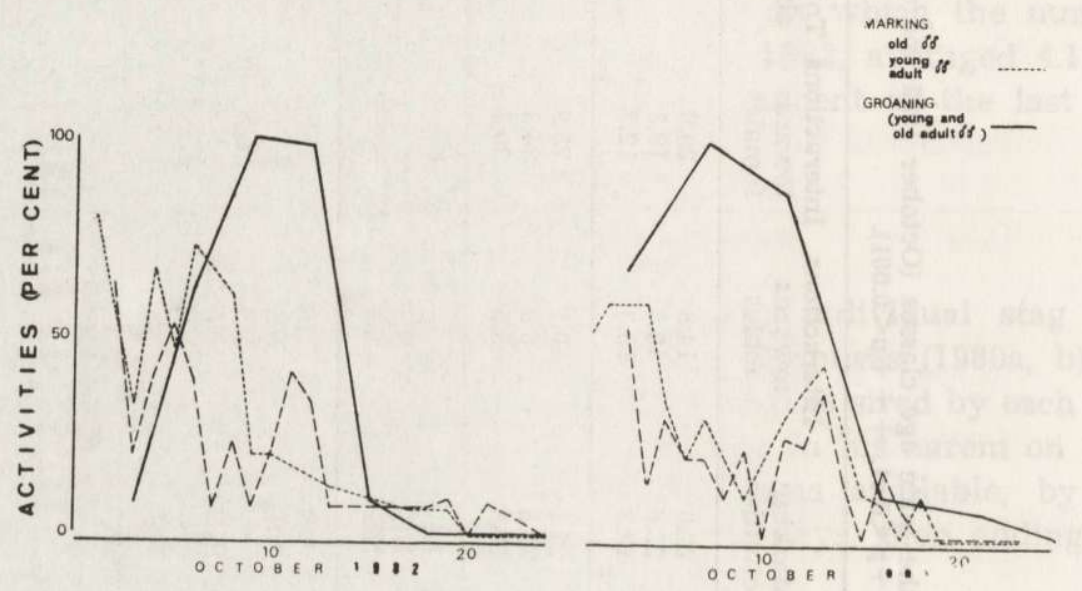

Fig. 3. Percentage of 1-min periods containing marking activity and groaning.

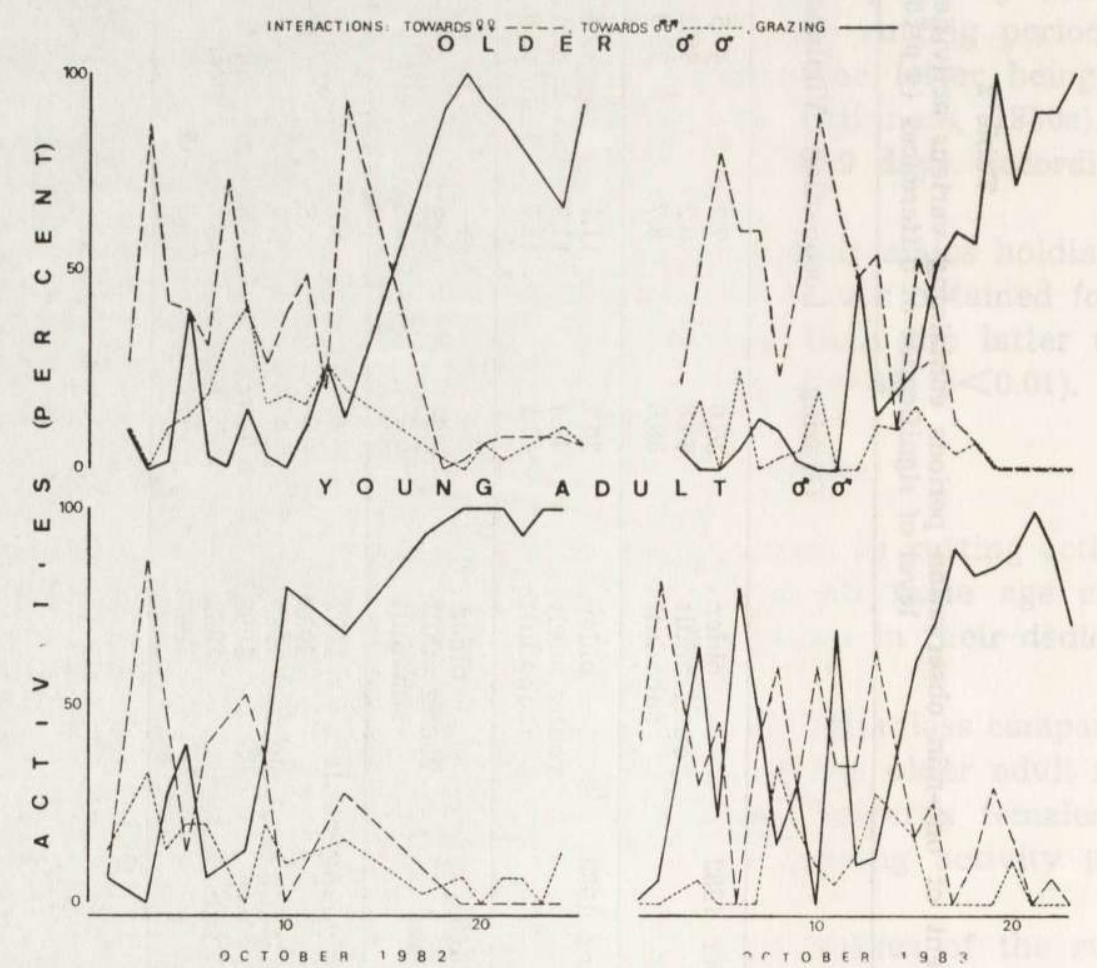

Fig. 4. Percentage of 1 -min periods containing interactions towards both males and females and grazing. 


\subsection{Sex and Age Classes Sociograms}

The sociograms between the sex and age classes are based on 617 interactions for the 1982 period (19 $\mathrm{h}$ and $23 \mathrm{~min}$ of observation) and of 1,754 interactions for 1983 ( $20 \mathrm{~h}$ and $49 \mathrm{~min}$ ).

The information obtained from a group under observation consisted of the number of interactions, the classes of individuals involved as actors and as receivers, the size and composition of the observed group and the time of observation. This information was useful to calculate interaction indices (Shank, 1972) among the different age and sex classes, whose values are the framework of the 1982 and 1983 sociograms shown in Fig. 5. Comparing the results for both study periods, we must note first the higher rate of interactions per min for the 1983 rutting season, as compared to that of 1982 (1.4 vs. 0.5). This increased rate is appaparently reflected in a higher involvement of all male age classes ir. the interactions toward females.
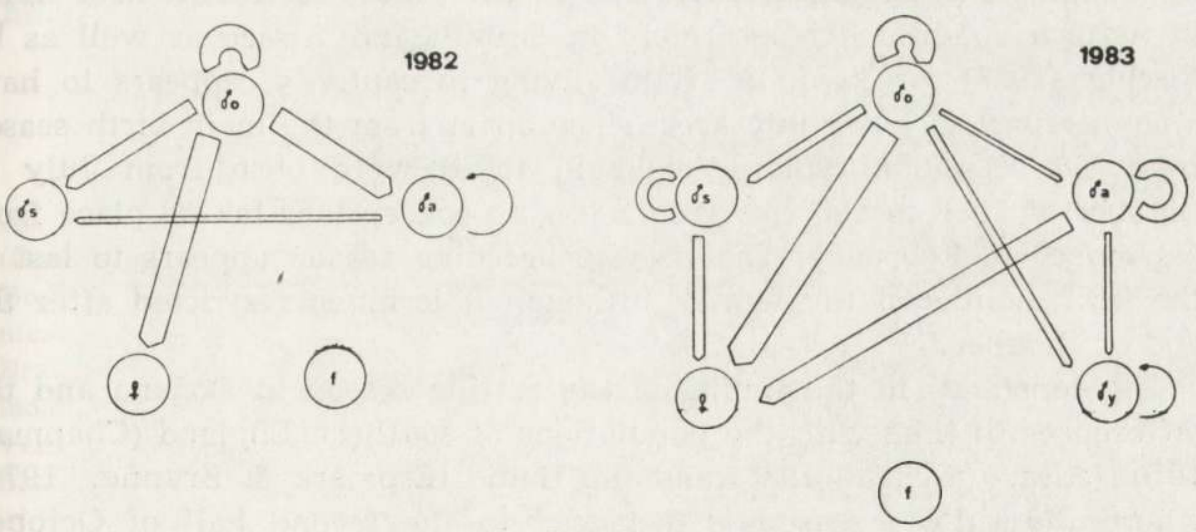

Fig. 5. Intra- and interclass sociograms of all kinds of interactions among the age and the sex classes. Thickness of arrows represent values of interaction indices

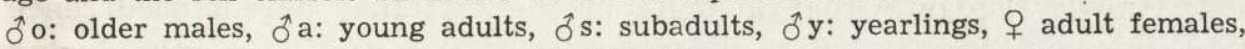
f: fawns).

\subsection{Space and Breeding Success}

Our first question was the relationship between preference for a given zone and the reproductive success of the males involved.

To that purpose we measured the distance between successive locations on a map of every individual adult male during the month of October, the obtained mean values were compared to his reproductive success and for the whole of the adult males the negative correlation was significant $\left(1982: r_{s}=-0.48, N=17, p<0.05 ; 1983: r_{s}=-0.54, N=15\right.$, 
$p<0.05$ ). That is, those males travelling along and not sticking to a given place showed the lowest reproductive success.

On the other hand, no significant differences were found among the various kreeding characteristics (reproductive success, harem size, holding duration in days of the males occupying the various zones of the study area).

\section{DISCUSSION}

First of all the information related to occurrence of mixed groups points towards a ruting season fixed in time, occupying at Donana mainly the first three weeks of October. This period started suddenly and decreased to the end gradually over the rest of the autumn, a very: similar pattern to that reported by Espmark \& Brunner (1974) for fallow deer on the Baltic island of Öland.

The extension of the reproductive period across the winter, reported by Chapman \& Chapman (1975) and Schaal (1985) for fallow deer living in natural conditions respectively in Britain and Alsace as well as by Fischer (1983) for juvenile groups living in captivity, appears to have a counterpart in our study area, since apart from the main birth season in June, occasional young (eight in total) were born from July to October of 1983 to 1985 , corresponding to conceptions taking place from November to February. That is, the breeding season appears to last to the first months of the winter, although it is much restricted after the end of October.

The constancy in the timing of the rutting season in Donana and the differences in time with the populations of southern England (Chapman, 1970), Alsace (Schaal, 1985) and the Baltic (Espmark \& Brunner, 1974), where the rutting season is displaced to the second half of October, appear to be in accord with the known photoperiodic control of the sex cycle in cervids (Jaczewski, 1954; Goss, 1969a, b).

We must also note that in spite of the fact that harem occurrence takes place during the first three weeks of October, it is only during the first fortnight that rutting activities are actually apparent: It is at this time when groaning is heard more often and the levels of interactions towards females and towards other males are the highest, probably indicating a maximum in the number of females conceiving, as it happens in the red deer (Clutton-Brock et al., 1982).

Marking activity is somewhat peculiar in this respect, as it occurs at the beginning of that fortnight, decreasing gradually afterwards, this situation being in agreement with previous descriptions of fallow deer behaviour (Espmark \& Brunner, 1974), where marking was at its maximum in the preliminary rutting phases. 
Our results concerning the more successful males and their attachment to particular areas, as well as those of Espmark \& Brunner (1974) and ours indicating a higher dedication to marking activities at the preliminary rutting phases would suggest that olfactory assessment during that previous period could be of importance in fallow deer reproduction. Phylopatry shown by the more successful rutting red deer stags (Lincoln \& Guinness, 1973) appears to apply also to our fallow bucks.

Our results for the 1982 period, when food availability was high and the population had just suffered a high mortality, might reflect a relationship between reproduction being allocated to the old males (as an effect of their control over the subadults and young adults) and a high breeding success.

During 1983, when food availability and breeding success were lower, the interactions towards other males were less frequent and their interclass hierarchy less organized. The control of old males over the other male classes was weaker, most of the male age classes getting involved in interactions towards females.

\section{REFERENCES}

1. Alvarez F., Braza F. \& Norzagaray A., 1975: Etograma cuantificado del gamo (Dama dama) en libertad. Doñana, Acta Vert. 2: 39-142.

1a. Braza, F., 1975: Censo del gamo (Dama dama) en Doñana. Naturalia Hispanica, 3: 1-27.

2. Braza F., Alvarez F., Geldof R. \& Byloo H., 1984: Desplazamientos de ungulados silvestres a través de una zona de ecotono en Doñana. Doñana, Acta Vert., 11: 275-287.

3. Braza F. \& Alvarez F., (in press): Habitat use by red deer and fallow deer in Doñana National Park.

4. Chapman D. I., 1970: Observations on the sexual cycle of male deer in Britain. Mammal Rev. 1: 49-52.

5. Chapman D., \& Chapman N., 1975: Fallow Deer. Terrence Dalton, Suffolk, England.

6. Clutton-Brock T. H., Guinness F. E. \& Albon S. D., 1982: Red deer. Behaviour and ecology of two sexes. Edinburgh Univ. Press.

7. Espmark Y. \& Brunner W., 1974: Observations on rutting behaviour in fallow deer, Dama dama (Linné, 1758). Saugetierk. Mitt. 2: 135-142.

8. Fischer K., 1983: Untersuchungen zur Fortpflanzungsfähigkeit von jungem Weiblichem und männlichem Damwild (Dama dama L.). Z. Jagdwiss., 29: 137-142 .

9. Gibson R. M. \& Guinness F. E., 1980a: Differential reproduction among red deer (Cervus elaphus) stags on Rhum. J. Anim. Ecol., 49: 199-208.

10. Gibson R. M. \& Guinness F. E., 1980b: Behavioural factors affecting male reproductive success in red deer (Cervus elaphus). Anim. Behav., 28: 1163-1174.

11. Goss R. J., 1969a: Photoperiodic control of antler cycles in deer. I. J. exp. Zool., 170: $311-324$. 
12. Goss R. J., 1969b: Photoperiodic control of antler cycles in deer. II. J. exp. Zool. 171: 223-234.

13. Heidemann G., 1973: Zür Biologie des Damwildes (Cervus dama L. 1758). Mammalia Depicta, 9, Verlag Paul Parey. Hamburg, Berlin.

14. Jaczewski Z., 1954: The effects of changes in length of daylight on the growth of antiers in the deer (Cervus elaphus). Folia Biol., 2: 133-143.

15. Jodra P. J., 1981: Parámetros del gregarismo del gamo (Dama dama) en el Coto de Doñana. Doñana, Acta Vert., 8: 237-289.

16. Lincoln G. A. \& Guinness F. E., 1973: The sexual significance of the rut in red deer. J. Reprod. Fert. 19: 475-489.

17. Ojeda J., Braza F., Alvarez F. \& Azcárate T., 1983: La población de gamos del Parque Nacional de Doñana, Acta Vert. 10: 221-224.

18. Schaal A., 1985: Observations préliminaires sur le cycle sexuel du daim, Cervus (Dama) dama L. Mammalia, 49: 288-291.

19. Shank C. C., 1972: Some aspects of social behaviour in a population of feral goats (Capra hircus L.). Z. f. Tierpsychol. 30: 488-528.

Accepted, May 20, 1986.

Francisco BRAZA, Juan E. GARCIA i Fernando ALVAREZ

\section{BEHAWIOR DANIELA W OKRESIE GODOWYM}

\section{Streszczenie}

Badano behawior daniela $w$ okresie godowym $w$ rezerwacie Doñana (poludniowo-zachodnia Hiszpania) w latach 1982-84. Okres godowy jest stały w ciągu roku, zaczyna się nagle na początku października, trwa jeszcze przez tydzień i następnie wygasa w ciągu jesieni. Średnia wielkość haremu mało różniła się w kolejnych sezonach (od 9.1 do 10.6), lecz w 1982 roku, kiedy wiosenne opady po raz pierwszy po długim okresie suszy osiągnęły normalny poziom, liczba haremów była najniższa. Natomiast liczba samic w haremie była najwyższa. Mniej byków utrzymywało haremy w 1982 roku, lecz osiągnęly one wyższy sukces rozrodczy, niż w następnych latach. W szczycie okresu godowego rykowisko oraz interakcje $\mathrm{z}$ osobnikami obu płci osiągają maximum, a żerowanie - minimum. Znakowanie terenu jest bardzo intensywne na początku okresu godowego i stopniowo zanika. Samce o najwyższym sukcesie rozrodczym wykazywały przywią. zanie do poszczególnych areałów godowych. 